\title{
THE ANTHROPOLOGICAL ANALYSIS OF A SKELETON DISCOVERED AT SUCIDAVA - CELEI (OLT COUNTY)
}

Gabriel Vasile

\section{ANALIZA ANTROPOLOGICĂ A UNUI SCHELET DESCOPERIT LA SUCIDAVA - CELEI (JUDET,UL OLT).}

\section{Rezumat}

Descoperit în campaniile de săpături arheologice din 1946-1947 de la Sucidava - Celei sub pavimentul primei bazilici paleocreştine de la nordul Dunării de către Dumitru Tudor, scheletul ce face obiectul studiului de față este de sex masculin, are o vârstă de aproximativ 36 de ani şi se încadrează în grupa taliilor mari. De asemenea, au fost identificate caracteristici ce aparțin tipului antropologic fizic nordic. La nivelul neurocraniului a fost evidențiat fenomenul de pseudo-plagiocefalie. Scheletul se prezintă într-o stare de conservare şi reprezentare relativ bună. Nu a putut fi stabilită cauza morţii.

Cuvinte cheie: Sucidava - Celei, paleocreştinism, determinarea sexului, estimarea vârstei şi taliei, pseudo-plagiocefalie, caractere nordice.

Keywords: Sucidava-Celei, paleochristianity, sex determination, age and stature estimation, pseudoplagiocephaly, Northern characters.

\section{Introduction}

In the archaeological digging campaigns from 1946-1947 at Sucidava Professor Dumitru Tudor discovered, in the north-west corner of the Romano-Byzantine fortress Sucidava Celei, the foundations of a Paleochristian basilica. This remains the first and only monument of the kind regarding the beginnings of Christianity north of Danube. The Paleochristian basilica discovered on the territory of the ancient Trajanic Dacia dates from the $6^{\text {th }}$ century A.D., being connected by the program lead by Justinian for spreading Christianity among the barbarian tribes and the Romanic population remained in Dacia after the Aurelian retreat. (Tudor, 1978: 465-466).

Inside the basilica, under the floor, were discovered six burial tombs, and in the immediate neighbourhood, towards west, another one. The dead were deposed in "sarcophagus" made of bricks or stones and bricks treated with mortar or clay, without roof; in the western extremity of one of the "sarcophagus", in the mild paste of one brick, was made a cross framed with a circle. The skeletons west-east oriented, didn't have an inventory, were seated on the back and were dated as the second half of the $6^{\text {th }}$ century A.D. (Toropu and Tătulea, 1987: 95-96).

The osseous remains which are the object of this study, belong to the tomb next to the pulpit (tomb no. 9), arranged with a convertible roof, so it can be visited (Toropu and Tătulea, 1987: 219-220) and were offered for an analysis by Mrs. Mirela Cojoc ${ }^{1}$.

Our motivation for studying this tomb, was stimulated partly by the fact that is was discovered under the pavement of the first Paleochristian basilica north of Danube, and partly because we were intrigued by the ancientness of the digging, considering the fact that it was studied in the years which followed World War Second.

\footnotetext{
${ }^{1}$ The Director of Archaeology and Ethnology Museum Corabia (Olt county), to whom we are warmly thanking for the material given for studying. We also like to thank Mr. PhD. Crişan Muşețeanu, General Director of National Romanian History Museum for giving us the endorsement to study this skeleton.
} 


\section{Descriptive characters}

The skeleton has a pretty good preservation condition and representation, and with few exceptions (due to the recent natural destructive factors), we can identify all the anatomical integrant elements.

Except for the skull, mandible, fibulas, metatarsals and the phalanxes of the inferior limbs, the rest on the anatomical elements are more or less impregnated with manganese oxides, resulted from the burial conditions. The oxides presents under the form of spots or very delicate blisters, of variable dimensions. We cannot surely say which is the source of the manganese oxides, because they are present in different kind of soils, not having a certain specific ${ }^{2}$.

The neurocranium has at the right parietal level a breaking ${ }^{3}$, while the left one is whole. At the occipital level only the squamous portion is present. In occipital norm, the neurocranium is visible baggy towards right, having a house shape. The external occipital protuberance is weakly evolved. We can't surely say if we are dealing with an ante-mortem or post-mortem deforming, artificial or natural. (picture 3 and picture 4, drawing 1). Still, in superior view the skull has a bursiform shape (picture 4, drawing $1)$, it is slightly asymmetrical ${ }^{4}$ and phenozygous (the left jugal arch is visible, while the right one is missing). The frontal is whole and there are also present both temporal bones, missing some elements which belong to tympanum area of the right temporal.

\footnotetext{
${ }^{2}$ We express our gratitude for the information he given to Mr. Constantin Haită, sedimentologist and micromorphologist, National Romanian History Museum, National Centre of Pluridisciplinary Researches.

${ }^{3}$ We mention that the neurocranium was offered for the analysis having anterior lacquering traces, probably for preservation and exposure. Unfortunately, this thing stops us to make some very important remarks for the study of this skeleton, regarding the moment in which the breaking has been made; in other words, if it is ancient or actual.

${ }^{4}$ The deformation can be due to osseous decalcifications, or, more precise, to some variations regarding the growth rate of the cranial bones, considerable changes could take place even when the bones are not decalcified (due to the earth pressure), phenomena known in the specialty literature under the name of pseudo-plagiocephaly (Brothwell, 1981: 172-173).
}

The viscerocranium is represented by the mandible, from which there are missing bilateral incisors, maxilla, jugals and nasals.

Except the L5 vertebra (whole), the rest of the vertebras are very fragmented; also, they all have a porous consistency. The first two cervical vertebras, atlas and axis, are missing.

All the ribs are present, strongly impregnated with manganese oxides, compared to the vertebras.

The sternum presents the manubrium and the body, and the xiphoid process is missing.

The right clavicle is represented only by the corresponding half of the acromial extremity, and the left one is almost whole.

The scapulas present strong oxides impregnations at the level of the costal faces, the right one being impregnated like spots shape on the posterior face either.

The right humerus is whole; from the left one the proximal epiphysis could not be recovered, and therefore restored. Also, it doesn't present olecranial perforations (picture 6 , drawing 2).

The bones of the forearm (radius and ulna) are whole, except the right ulna from which the distal epiphysis is missing.

The innominate bones and the sacrum are relatively complete, lacking only some small fragments at the innominate bones level, which also have a porous consistency.

The femurs and tibias, strong bones, kept entirely, being impregnated only with small spots by the manganese oxides from the soil.

A small fragment was identified at the level of the patella (probably belonging to the right patella).

Both distal epiphyses of the fibulas are missing.

From the hand and foot skeleton are present both pairs of taluses and calcanei, and the metatarsi, metacarpi and phalanxes are in incomplete number.

\section{Sex establishing}

The individual subjected to the analysis is no doubt a male. We were led to this result by the skull characteristics, and by those of the postcranial skeleton, as it follows: 
- prominent glabella and supraciliary arches;

- high, retreated forehead (picture 2, drawing 1);

- burly and prominent mastoid apophysis;

- long bones with developed muscular relief, massive epiphysis;

- narrow and more arched sacrum than at females (picture 7, drawing 2);

- innominate bones have the iliac crest in an "S" shape, developed muscular relief, and the greater sciatic notch is in "U" shape (picture 8, drawing 2);

To these adds the value of Schultz's ischium-pubis index (86.21 for the right side and 88.83 for the left one), no doubt the only one which establishes for certain the $\mathrm{sex}^{5}$.

\section{Age estimation}

When all the epiphysis are merged and all teeth broke out, the question of death age estimation becomes difficult, the main parameters remaining the dental usage, the obliteration degree of the cranial sutures, the changes at the pubian diaphysis surface level and the resorption of the spongy tissue from the humerus and femur proximal epiphysis, observed through sagittal sections. Although in this study we only used the first two parameters ${ }^{6}$, we mustn't omit the fact that the synostosis of the sutures varying from one individual to another, from one sex to another and also from one suture to another (Olivier, 1960: 149). Identical, in the case of the dental attrition for age estimation, we must consider the applicability of one or another dental attrition model of the different authors. In our case the skeleton dates from the second half of the $6^{\text {th }}$ century A.D., and in the estimation of age we used Brothwell's model (1981: 72), who analysed Anglo-Saxon British groups whose skeleton material dates from the Neolithic until the Middle Age (Hillson, 1996: 195), therefore including groups which didn't suffer any dramatic changes

\footnotetext{
${ }^{5}$ The values of this index frame between 73-94 at men and between 91-115 at women (Bass, 1987: 193).

${ }^{6}$ The surface of the pubian diaphysis is not intact; to visualise the resorption of the spongy tissue from the proximal epiphysis of humerus and femur, the sagittal section of the two anatomical elements is necessary, a thing that wasn't done because the skeleton is to be exposed at the Archaeology and Ethnology Museum in Corabia; because of this aspect we considered that it would be preferable to remain intact.
}

in their diet face to the ancient populations (Stirland, 2003: 33) correlated with our individual.

We subjected to the analysis the coronal, lambdoid and sagittal sutures (exocranial and endocranial). After Olivier, the estimated age (based on the age averages of the sutures sectors) is 42.5 years.

The dental attrition is not very advanced (picture 5, drawing 2), the attrition degrees (represented with thickened numbers) and the relative age in the following table:

\begin{tabular}{|c|c|c|c|}
\hline \multirow{2}{*}{} & \multicolumn{3}{|c|}{ mo1ar } \\
\cline { 2 - 4 } & M1 & M2 & M3 \\
\hline left mandible & $\mathbf{4}(25-35)$ & $\mathbf{4}(25-35)$ & $\mathbf{3}-(25-35)$ \\
\hline right mandible & $\mathbf{4}(25-35)$ & $\mathbf{3}(25-35)$ & $\mathbf{3 -}(33-45)$ \\
\hline left maxilla & $\mathbf{5}(25-35)$ & $\mathbf{3 -}(17-25)$ & \\
\hline right maxilla & $\mathbf{4 + ( 2 5 - 3 5 )}$ & & \\
\hline
\end{tabular}

Therefore, after the dental attrition, the subject analysed is around 30 years old, according to the age's averages for each molar.

Combining the results obtained after the analysis of the two parameters, we obtain a decease age for this individual around the age of 36.25 years, so we are including him in the adult age category (after Stirland, 2003: 33) or maturus I (after Maximilian, 1962: 91).

\section{Stature estimation}

To calculate this parameter we used Rösing's methods (1988: 597, after Pearson 1899) and Trotter (1970: 74).

After Rösing the stature was estimated considering the maximal length of humeruses $(H)$, radiuses $(R)$, femurs $(F)$ and tibias $(T)$, as it follows:

\begin{tabular}{|l|c|c|}
\hline anatomical element & left (cm) & right (cm) \\
\hline $\mathrm{H}$ & - & 172.63 \\
\hline $\mathrm{R}$ & 174.28 & 175.35 \\
\hline $\mathrm{F}$ & 171.72 & 173.51 \\
\hline $\mathrm{T}$ & 179.03 & 179.17 \\
\hline $\mathrm{H}+\mathrm{R}$ & - & 172.24 \\
\hline $\mathrm{H}+\mathrm{F}$ & - & 174.15 \\
\hline $\mathrm{F}+\mathrm{T}$ & 176.24 & 177.47 \\
\hline stature average $^{7}$ & - & $\mathbf{1 7 4 . 9 3}$ \\
\hline
\end{tabular}

\footnotetext{
7 Only the elements on the right side were totally present, based on the average of their maximum length values the stature being $174.93 \mathrm{~mm}$.
} 
According to Trotter, stature estimation was made based on the maximum length values of the femur. It was obtained a value of 177.53 $\mathrm{cm}$ for the left femur and $179.79 \mathrm{~cm}$ for the right one, so in average, $178.66 \mathrm{~cm}$.

Corresponding to the stature values obtained based on the two methods, we conclude that we are dealing with an individual who fits the large stature category (after Necrasov et alii, 1959: 28).

\section{Anthropological characterization}

The values of the cranial dimensions and parameters indicate a subject who without any doubt frames into the Northern physical anthropological type. Although the Northern population possesses features similar to the Mediterranean one, our individual differentiates from this one by a high stature $-174.93 \mathrm{~cm}$ after Pearson and $178.66 \mathrm{~cm}$ after Trotter little after the average of this population type ${ }^{8}$, long skull (very long in our case, $203.90 \mathrm{~mm}$ ) and elongated (dolicocrany, 73.98), relative strong supraorbital region unlike the Mediterranean, relative straight and narrow (stenometopy, 63.61), occipital which stretches long way back, rounded orbits ${ }^{9}$, hypsiconchy (width, with an average of the breadth values of 44.02 , so which tends towards the inferior limit of the very breadth category), high nose, mesorrhyn (after Olivier, 1960: 134) and leptorrhyn after Bass (1987: 75-76), high face with a total facial height of $88.64^{10}$, mesoprosopy (but towards the limit leptoprosopy), meseny (51.87), mandible with pronounced osseous relief, width or short (brachignat, 73.27), high cranial capacity (1660.52 $\mathrm{cm}^{3}$, aristencephal), all specific elements for the Northern type (Maximilian, 1959: 95).

\footnotetext{
8 The average of men stature at the Northern populations is a little higher $(174 \mathrm{~cm})$ compared to the Mediterranean populations (Maximilian, 1959: 95).

${ }^{9}$ We should mention that the sexual dimorphism, based on this morphological characteristic having to deal with quadratic orbits, subrectangular in men case and with rounded orbits at women (Acsádi and Nemeskéry, 1970: 76, 78).

${ }^{10}$ Northern populations have a parameter around 90 (Maximilian, 1959: 95).
}

From the main characters, dimensions and indices of limbs and girdle bones, the following ones are drawing our attention:

- the glenoid index of the right scapula (72.54), indicates an oval glenoid cavity;

- very high humeral diaphysar section index (over 90), attests the lack of flattening at this level, the diaphysis having a round shape in section;

- the brachial (radiohumeral) index belongs to the medium category (79.82), so we are dealing with a medium radius;

- the Verneau index of transversal flattening of ulna (platoleny), indicate a euroleny (middle ulnas), in change the value situating at the upper limit of the middle category, correlated with flattening degree of humerus;

- the values of the femurs pilaster index ( 90.67 for the left one and 97.74 for the right one), shows a null pilaster (linea aspera); they are also rounded in subtrochanter section according to the values of the platymeric index (eurimery). Although the two platymeric indices are framed into the eurimery category, their values (88.59 for the left and 96.68 for the right femur) suggest a slight asymmetry;

- the tibial platycnemic indices approve a null flattening at the level of the nutritive fosse, flattening in rapport with femur platimery.

According to these, our subject was without any doubt right handed. Proof of this are the midshaft circumference values of the humerus (64.00 for the left one and 70.00 for the right one), and of the least circumference of the shaft measured at the level of the radial bicipital tuberosity. This thing can be explained by the intense effort tension specific for the right hand. 


\section{Pathology}

Except for the pseudo-plagiocephaly, at the level of the whole skeleton weren't identified pathology elements. In particular, also, at the dentition level weren't found dental caries, periodontal diseases, gravels, abscesses, hypoplasias or other dental anomalies.

\section{Discussions and conclusions}

The archaeological information we had (,sarcophagus" which presents a cross framed by circle, a skeleton west-east oriented placed on the back, the tomb didn't had an inventory), are the main indicators of the fact that the individual subjected to the analysis was without any doubt a Christian. The discovery of the skeleton under the floor of a basilica from the $6^{\text {th }}$ A.D. on the territory of the ancient Trajanic Dacia province (for this territory north of Danube, the discovery is the first of the kind), likens mainly with the situation found in Dobrogea at Murighiol. Here was discovered, under the altar inside the basilica of the ancient Romano-Byzantine fortress Halmyris, a crypt which contained numerous human relics (Miritoiu and Soficaru, 2003: 531), some of these being attributed by the authors of the research to the martyrs Epictet and Astion, executed by beheading at $8^{\text {th }}$ of July 290 A.D. A very important aspect is the fact that at Murighiol, compared to Sucidava, we also find unchristian burials. Therefore the resemblance consists only in the fact that in both cases the burial was made under the basilica. Discoveries of the kind were not recorded, but in change, only on the Dobrogea territory - at Adamclisi (Tropaeum Traiani), Slava Rusă and Niculițel. Both at Adamclisi and Niculițel, we are dealing with martyrs.

The anthropological information which resulted from the osteological remains analysis, indicates a subject which belongs to the Northern type, which has as main characteristics a very long maximum cranial antero-posterior diameter $(203.90 \mathrm{~mm})$, maximum breadth included into the limits of medium category $(150.85 \mathrm{~mm})$ and adequate horizontal cranial index situated in the dolicocrany category (73.98); cranial relief more pronounced than that belonging to the Mediterranean type - dull or weekly developed - (Maximilian, 1962: 146), more burly and very breadth face (picture 1, drawing 1) with a bizygomatic diameter of $141.31 \mathrm{~mm}$ and taller stature, little over the average of this physical anthropological type.

Unfortunately, lacking the physical anthropological studies (satisfactory as a number) for this period and for the beginnings of Christianity north of Danube, we couldn't make but few comparisons with similar cases encountered in Dobrogea.

The cause of death couldn't be established, and the lack of the first two cervical vertebras stopped us to assert if our subject had a death similar to the martyrs we mentioned or another one. 
(a) main dimensions and parameters of the cranial skeleton

\begin{tabular}{|c|c|c|}
\hline Martin numbers / dimensions and parameters & values $^{11}$ & category $^{12}$ \\
\hline 1. maximum length $(\mathrm{g}-\mathrm{op})$ & 203.90 & very long \\
\hline 2. $g-i$ & 200.10 & \\
\hline 2a. $n-\mathrm{i}$ & 193.38 & \\
\hline 3. $g-1$ & 196.77 & \\
\hline 3 a. $n-1$ & 202.14 & \\
\hline 8. maximum breadth $(\mathrm{eu}-\mathrm{eu})$ & 150.85 & medium \\
\hline 9. minimum frontal breadth $(\mathrm{ft}-\mathrm{ft})$ & 95.96 & narrow \\
\hline 10. maximum frontal breadth (co - co) & 116.89 & narrow \\
\hline 11. breadth of the skull base $(\mathrm{au}-\mathrm{au})$ & 129.01 & \\
\hline 12. ast - ast & 115.41 & \\
\hline 13. $\mathrm{ms}-\mathrm{ms}$ & 115.70 & \\
\hline 20. skull height (po - b) & 115.90 & \\
\hline 26. sagittal frontal $\operatorname{arch}(\mathrm{n}-\mathrm{b})$ & 128.00 & \\
\hline 26 a. $\operatorname{arch}(g-b)$ & 119.00 & \\
\hline 27. sagittal parietal arch $(b-1)$ & 126.00 & \\
\hline 28 (1). superior occipital $\operatorname{arch}(1-i)$ & 62.00 & \\
\hline 29. frontal chord $(n-b)$ & 115.90 & \\
\hline 29 d. chord $(g-b)$ & 109.72 & \\
\hline 30. parietal chord $(b-1)$ & 122.54 & \\
\hline 31 (1). superior occipital chord $(1-\mathrm{i})$ & 57.69 & \\
\hline 38. cranial capacity (Lee - Pearson) & 1660.52 & high \\
\hline I 1. horizontal cranial index $(8: \mathbf{1})$ & 73.98 & dolicocrany \\
\hline I 4. vertico - longitudinal index $(\mathbf{2 0}: \mathbf{1})$ & 56.84 & chamaecrany \\
\hline I 5. vertico - transversal index $(\mathbf{2 0}: \mathbf{8})$ & 76.83 & tapeinochrany \\
\hline I 12. frontal transversal index $(\mathbf{9}: \mathbf{1 0})$ & 82.09 & intermediary \\
\hline I 13. fronto - parietal transversal index $(9: 8)$ & 63.61 & stenometopy \\
\hline I 13 a. coronal - parietal index $(10: 8)$ & 77.48 & \\
\hline I 14. parieto-occipital transversal index $(\mathbf{1 2}: \mathbf{8})$ & 76.50 & medium \\
\hline$(12: 9)$ & 120.26 & \\
\hline I 16. fronto - parieto sagittal index $(27: \mathbf{2 6})$ & 98.43 & \\
\hline I 22. frontal curvature index $(\mathbf{2 9}: \mathbf{2 6})$ & 90.54 & chamemetopy \\
\hline - frontal curvature index (29 d : 26 a) & 92.20 & \\
\hline I 24. parietal curvature index $(\mathbf{3 0}: \mathbf{2 7})$ & 97.25 & \\
\hline I 26. occipital superior curvature index [31 (1): 28 (1)] & 93.04 & \\
\hline 44. $\mathrm{ek}-\mathrm{ek}$ & 109.38 & \\
\hline 45. facial width (bizygomatic breadth) (zy - zy) & $(141.31)^{13}$ & very broad \\
\hline 47. total facial height $(\mathrm{n}-\mathrm{gn})$ & 125.26 & high \\
\hline 48. upper facial height $(n-p r)$ & 73.30 & very high \\
\hline 50. $\mathrm{mf}-\mathrm{mf}$ & 25.52 & \\
\hline
\end{tabular}

\footnotetext{
${ }_{11}^{11}$ All the values of the dimensions are given in mm, only the cranial capacity being expressed in $\mathrm{cm}^{3}$.

12 The classifying on categories was made after Olivier (1960).

13 The values in the brackets, suggest the fact that the bones are not entirely whole, lacking small portions, and because of this the biometric values are approximate.
} 


\begin{tabular}{|c|c|c|}
\hline Martin numbers / dimensions and parameters & values & category \\
\hline 51. right orbital breadth $(\mathrm{mf}-\mathrm{ek})$ & 44.05 & broad \\
\hline 51. left orbital breadth $(\mathrm{mf}-\mathrm{ek})$ & 43.99 & broad \\
\hline 52. right orbital height & 38.61 & very high \\
\hline 52. left orbital height & 38.09 & very high \\
\hline 54. nasal breadth $(\mathrm{al}-\mathrm{al})$ & 26.35 & broad \\
\hline 55. nasal height $(\mathrm{n}-\mathrm{ns})$ & 55.86 & very high \\
\hline 61. maxilloalveolar breadth (palatal breadth) & 65.09 & \\
\hline 62. maximum palatal length $(\mathrm{ol}-\mathrm{sta})$ & 47.56 & \\
\hline 63. maximum palatal breadth (enm - enm) & 42.53 & \\
\hline 80 (2). length pm $1-\mathrm{m} 3$ (maxilla) & 34.19 & \\
\hline I 38. total facial index $(\mathbf{4 7}: \mathbf{4 5})$ & 88.64 & mesoprosopy \\
\hline I 39. upper facial index $(\mathbf{4 8}: \mathbf{4 5})$ & 51,87 & meseny \\
\hline fronto - gonial index $(\mathbf{6 6}: 9)$ & 120.97 & \\
\hline I 42. right orbital index $(\mathbf{5 2}: \mathbf{5 1})$ & 87.65 & hypsiconchy \\
\hline I 42. left orbital index $(\mathbf{5 2}: \mathbf{5 1})$ & 86.58 & hypsiconchy \\
\hline I 48. nasal index $(\mathbf{5 4}: \mathbf{5 5})$ & 47.17 & mesorrhiny/leptorrhiny \\
\hline I 58. palatal index $(63: 62)$ & 89.42 & brachystaphyline \\
\hline 65. bicondylar breadth $(\mathrm{kdl}-\mathrm{kdl})$ & 137.04 & \\
\hline 66. bigonial breadth $($ go - go $)$ & 116.09 & \\
\hline 68 (1). projection length ${ }^{14}$ & 100.41 & \\
\hline 69. height of mandibular symphysis (idi - gn) & 31.41 & \\
\hline 69 (1). mandible body height & $33.56 / 28.34$ & \\
\hline 70. height (length) of ascending ramus & 66.67 & \\
\hline 71. breadth of ascending ramus & 35.10 & \\
\hline 71 a. minimum breadth of ascending ramus & 33.84 & \\
\hline 80 (2). length pm1 - m3 (mandible) & 38.03 & \\
\hline I 62. mandible index $[68(1): 65]^{15}$ & 73.27 & brachignat \\
\hline I 64. mandible / gonio - condilian breadth index $(\mathbf{6 6}: \mathbf{6 5})$ & 84.71 & \\
\hline maxilloalveolar length (palatal length) (pr: alv) (Bass) & $48.30^{16}$ & \\
\hline porion - height index $20:(\mathbf{8}+\mathbf{1}) / \mathbf{2}$ (Bass) & 65.34 & low \\
\hline transversal cranial - facial index (45:8) (Bass) & 93.67 & \\
\hline maxilloalveolar index $61:(\mathrm{pr}:$ alv) (Bass) & 134.76 & brachyurany \\
\hline
\end{tabular}

\footnotetext{
${ }^{14}$ This dimension was calculated by projection, from the most anterior point of the menton (pogonion), until the tangent plan of the posterior part of the two lateral condilion.

${ }^{15}$ In this study, in order to calculate the mandible parameter, we replaced the total length of the mandible, corresponding to number 68 (Martin), with that of the projection, that is with number Martin 68 (1).

${ }^{16}$ We should mention that where Martin numbers were not used, between the brackets was specified the author after whom we undertook the dimensions or the indices; this observation is also valid for the tables at point (b), which include the main dimensions and indices of the postcranial skeleton.
} 
(b) main dimensions and parameters of the postcranial skeleton

\begin{tabular}{|c|c|c|c|}
\hline Martin numbers / dimensions and parameters & left & right & category \\
\hline \multicolumn{4}{|l|}{ scapula } \\
\hline 12. glenoid cavity length & $(41.01)$ & 44.36 & \\
\hline 13. glenoid cavity breadth & & 32.18 & \\
\hline glenoid index $=\mathbf{1 3} \times 100 / \mathbf{1 2}$ & & 72.54 & \\
\hline \multicolumn{4}{|l|}{ humerus } \\
\hline 1. maximum length & & 357.29 & \\
\hline 2. physiological length & & 351.21 & \\
\hline 5. maximum diameter midshaft & 21.16 & 23.75 & \\
\hline 6. minimum diameter midshaft & 19.89 & 23.08 & \\
\hline diaphysar section index $=6 \times 100 / 5$ & 93.99 & 97.17 & euribrachy \\
\hline 7. least circumference of the shaft & 60.00 & 67.00 & \\
\hline robusticity index $=7 \times 100 / 1$ & & 18.75 & \\
\hline 7 a. midshaft circumference & 64.00 & 70.00 & \\
\hline brachial (= radiohumeral) index ${ }^{17}$ & & 79.82 & \\
\hline humerofemural index ${ }^{18}$ & & 70.62 & \\
\hline \multicolumn{4}{|l|}{ radius } \\
\hline 1. maximum length & & 280.37 & \\
\hline 1 b. physiological length & & 272.48 & \\
\hline 3. least circumference of the shaft ${ }^{19}$ & 42.00 & 43.00 & \\
\hline least circumference index $=\mathbf{3} \times 100 / \mathbf{1}$ & & 15.33 & \\
\hline 4. maximum transverse diameter midshaft & 16.09 & 18.11 & \\
\hline 5. minimum sagittal diameter midshaft & 13.91 & 13.86 & \\
\hline midshaft index $=\mathbf{5} \times 100 / \mathbf{4}$ & 86.45 & 76.53 & \\
\hline \multicolumn{4}{|l|}{ ulna } \\
\hline 2. physiological length & 291.45 & & \\
\hline 3. least circumference of the shaft & 39.00 & & \\
\hline caliber index $=\mathbf{3} \times 100 / \mathbf{2}$ & 13.38 & & \\
\hline 11. subsigmoidal sagittal index & 26.27 & 26.51 & \\
\hline 12. subsigmoidal transversal index & 25.13 & 26.12 & \\
\hline platoleny index $(=$ section index $)=\mathbf{1 2} \times 100 / 11$ & 95.66 & 98.52 & euroleny \\
\hline \multicolumn{4}{|l|}{ vertebrae (l 5) (Olivier) } \\
\hline a. anterior height & \multicolumn{2}{|c|}{36.63} & \\
\hline b. posterior height & \multicolumn{2}{|c|}{35.08} & \\
\hline lumbar index $=\mathbf{b} \times 100 / \mathbf{a}$ & \multicolumn{2}{|c|}{95.76} & citorahic \\
\hline
\end{tabular}

\footnotetext{
${ }^{17}$ Radius 1 x 100 / humerus 2.

${ }^{18}$ Humerus 2 x 100 / femur 2 .

${ }^{19}$ It was determined under the radial bicipital tuberosity.
} 


\begin{tabular}{|c|c|c|c|}
\hline Martin numbers / dimensions and parameters & left & right & category \\
\hline \multicolumn{4}{|l|}{ sacrum (Bass) } \\
\hline a. maximum anterior height & \multicolumn{2}{|c|}{107.29} & \\
\hline b. maximum anterior breadth & \multicolumn{2}{|c|}{108.54} & \\
\hline sacral index $=\mathbf{b} \times 100 / \mathbf{a}$ & \multicolumn{2}{|c|}{101.16} & \\
\hline \multicolumn{4}{|l|}{ innominate bones } \\
\hline a. maximum breadth (Bass) & & 170.12 & \\
\hline 9. maximum height & 232.42 & 232.86 & \\
\hline breadth index $=\mathbf{a} \times 100 / \mathbf{9}$ & & 73.05 & \\
\hline 9 a. ilium height & 152.26 & 150.23 & \\
\hline ilium breadth index $=\mathbf{a} \times 100 / \mathbf{9} \mathbf{a}$ & & 113.23 & \\
\hline 14 (1). cotylo - sciatic breadth & 40.26 & 40.19 & \\
\hline 15 a. ischium length & 98.00 & 96.36 & \\
\hline 17 a. pubis length & 84.49 & 85.60 & \\
\hline ischium - pubis index $=\mathbf{1 7} \mathbf{a} \times 100 / \mathbf{1 5} \mathbf{a}$ & 86.21 & 88.83 & \\
\hline \multicolumn{4}{|l|}{ femur } \\
\hline 1. maximum length & 487.94 & 497.45 & \\
\hline 2. bicondylar (= oblique or physiological) length & 487.39 & 497.29 & \\
\hline 6. sagittal diameter at the midshaft & 32.28 & 33.85 & \\
\hline 7. transversal diameter at the midshaft & 35.60 & 34.63 & \\
\hline robusticity index $=(\mathbf{6}+7) \times 100 / 2$ & 13.92 & 13.77 & \\
\hline pilastric index $(=$ middle section parameter $)=6 \times 100 / 7$ & 90.67 & 97.74 & null \\
\hline 8. circumference of the midshaft & 101.00 & 102.00 & \\
\hline robusticity index $=\mathbf{8} \times 100 / \mathbf{2}$ & 20.72 & 20.51 & \\
\hline 9. subtrochanteric transverse diameter & 35.95 & 35.01 & \\
\hline 10. subtrochanteric sagittal diameter & 31.85 & 33.85 & \\
\hline platymeric index $(=$ superior section $)=\mathbf{1 0} \times 100 / \mathbf{9}$ & 88.59 & 96.68 & eurimery \\
\hline 18. vertical (= frontal) diameter of the head & 52.02 & 55.29 & \\
\hline 19. maximum horizontal diameter of the head & 47.63 & 48.61 & \\
\hline section index of the head $=\mathbf{1 9} \times 100 / \mathbf{1 8}$ & 91.56 & 87.91 & \\
\hline robusticity index of the head $=(\mathbf{1 9}+\mathbf{1 8}) \times 100 / \mathbf{2}$ & 20.44 & 20.89 & \\
\hline 21. maximum transversal length of the inferior epiphysis & 76.05 & 82.25 & \\
\hline $\begin{array}{l}\text { the inferior extremity massiveness index } \\
\text { - face to the bicondylar length }=\mathbf{2 1} \times 100 / \mathbf{2} \\
\text { - face to the transversal diameter at the midshaft }=\mathbf{7} \times 100 / \mathbf{2 1}\end{array}$ & $\begin{array}{r}15.60 \\
46.81\end{array}$ & $\begin{array}{l}16.53 \\
42.10 \\
\end{array}$ & \\
\hline intermembral index ${ }^{20}$ & & 69.38 & \\
\hline \multicolumn{4}{|l|}{ tibia } \\
\hline 1. lateral length & 420.25 & 421.56 & \\
\hline 1 a. maximum length & 430.88 & 431.48 & \\
\hline 1 b. medial length & 422.96 & 423.12 & \\
\hline 3. breadth of the proximal epiphysis & 95.13 & 95.47 & \\
\hline 6. breadth of the distal epiphysis & 76.25 & 78.16 & \\
\hline 8. sagittal diameter at the midshaft & 34.34 & 33.71 & \\
\hline 8 a. sagittal diameter at the nutrient foramen & 36.68 & 35.96 & \\
\hline
\end{tabular}

\footnotetext{
${ }^{20}$ (humerus $\mathbf{1}+$ radius $\mathbf{1}$ ) x $100 /$ femur $\mathbf{1}+$ tibia $\mathbf{1}$.
} 


\begin{tabular}{|c|c|c|c|}
\hline Martin numbers / dimensions and parameters & left & right & category \\
\hline 9. transversal diameter at the midshaft & 27.79 & 28.10 & \\
\hline midshaft index $=\mathbf{9} \times 100 / 8$ & 80.92 & 83.35 & \\
\hline 9 a. transversal diameter at the nutrient foramen & 26.97 & 28.56 & \\
\hline platycnemic index $=\mathbf{9} \mathbf{a} \times 100 / \mathbf{8} \mathbf{a}$ & 73.52 & 79.42 & euricnemy \\
\hline 10. midshaft circumference & 92.00 & 92.00 & \\
\hline 10 b. least circumference of the shaft & 85.00 & 86.00 & \\
\hline robusticity (length - thickness) index $=\mathbf{1 0}$ b x $100 / \mathbf{1}$ & 20.22 & 20.40 & \\
\hline crural (= tibiofemural) parameter ${ }^{21}$ & 86.78 & 85.08 & \\
\hline tibioradial index ${ }^{22}$ & & 66.50 & \\
\hline \multicolumn{4}{|l|}{ talus } \\
\hline 1. maximum length & 62.66 & 62.65 & \\
\hline 2. minimum breadth & 49.66 & 49.88 & \\
\hline length - breadth index $=\mathbf{2} \times 100 / \mathbf{1}$ & 79.25 & 79.61 & \\
\hline 3. maximum height & 34.14 & 35.11 & \\
\hline length - height index $=\mathbf{3} \times 100 / \mathbf{1}$ & 54.48 & 56.04 & \\
\hline \multicolumn{4}{|l|}{ calcaneus } \\
\hline 1. maximum length & 80.59 & 83.04 & \\
\hline 2. minimum breadth & 29.16 & 29.74 & \\
\hline length - breadth index $=\mathbf{2} \times 100 / \mathbf{1}$ & 36.18 & 35.81 & \\
\hline 4. minimum height & 41.83 & 40.57 & \\
\hline length - height index $=\mathbf{4} \times 100 / \mathbf{1}$ & 51.90 & 48.85 & \\
\hline
\end{tabular}

\section{BIBLIOGRAPHY}

Acsádi G., Nemeskéry J., 1970, History of human life span and mortality, Académiai Kiadó, Budapest.

Bass W. M., 1987, Human osteology.

Baumann V., H., 1972, Nouveaux témoignages chrétiens sur le limes nord-sczthique. La basilique à martyrium de basse époque romaine découverte à Niculițel (dép. de Tulcea), Dacia, nouvelle serie, tome 16, p. 189-202.

Brothwell D., R., 1981, Digging up bones, $3^{\text {rd }}$ edition, Cornell University Press, Ithaca, New York.

Georgescu D., Pescaru M., 2001, Practicum de biologie umană, Editura Ars Docendi, București.

Hillson S., 1996, Teeth, Cambridge manuals in archaeology, Cambridge University Press.

Martin R, 1914, Lehrbuch der Anthropologie, Verlag von Gustav Fischer, Jena.

Maximilian C., 1962, Sărata Monteoru-Studiu antropologic, Editura Academiei Republicii Populare Române, Bucureşti.

Maximilian C., 1959, Studiul antropologic al populației de la Verbicioara (secolele XIII-XIV), Probleme de Antropologie, Editura Academiei Republicii Populare Române, vol. IV, p. 79-104.

Mirițoiu N., Nicolăescu-Plopşor D., 1978, Analiza antropologică a osermintelor descoperite în cripta bazilicii "simple" (A) de la Tropaeum Traiani, Pontica, XI, Muzeul de Arheologie Constanța, p. 189-207.

Mirițoiu N., Soficaru A. D., 2003, Studiu antropologic al osemintelor din cavoul romano-bizantin "Tudorca" de la Slava Rusă (antica Ibida), Peuce, new series, I (XIV), Tulcea, p. 511-530.

Mirițoiu N., Soficaru A. D., 2003, Studiu antropologic al osemintelor descoperite în cripta basilicii de la Murighiol (anticul Halmyris), Peuce, new series, I (XIV), Tulcea, p. 531-580.

\footnotetext{
${ }^{21}$ tibia 1 b x $100 /$ femur 2 .

${ }^{22}$ radius $1 \times 100 /$ tibia 1 .
} 
Necrasov O., Cristescu M., Maximilian C. şi Nicolăescu-Plopşor D., 1959, Studiu antropologic al scheletelor neolitice, descoperite în cimitirul preistoric de la Cernavodă, Probleme de Antropologie, Editura Academiei Republicii Populare Române, vol. IV, p. 23-45.

Olivier G., 1960, Pratique anthropologique, Vigot Frères, Éditeurs, 23, Rue de l'Ecole de Médicine, 23Paris- $\mathrm{VI}^{\mathrm{e}}$.

Papilian V., 2003, Anatomia omului, volume I, Aparatul locomotor, XIth edition, Editura All, ClujNapoca.

Pearson K., 1899, On the reconstruction of stature of prehistoric races. Philosophical Transactions of the Royal Society, ser. A, 192, p. 169-244.

Rösing F. W., 1988, Körperhöhenrekonstruktion aus skelettmaßen, în Anthropologie, Handbuch der vergleichenden biologie des menschen, Gustav Fischer Verlag, Stuttgart-New York, p. 586-599.

Stirland A., 2003, Human bones in archaeology, 2nd edition, A shire archaeology book, 46, Buckinghamshire, UK.

Toropu O., Tătulea C., 1987, Sucidava Celei, Editura Monumente şi Muzee, Bucureşti.

Trotter M., 1970, Estimation of stature from intact long limb bones, in T. D. Stewart (editor), Personal identification in mass disasters, Washington D. C., National Museum of Natural History, Smithsonian, p. 71-83.

Tudor D., 1978, Oltenia Romană, IV ${ }^{\text {th }}$ edition, Editura. Academiei Republicii Socialiste România, Bucureşti.

\section{LISTA ILUSTRAṬIEI}

Pl. 1 - Foto 1. craniu - norma facialis, Foto 2. craniu - norma lateralis, Foto 3. craniu - norma occipitalis, Foto 4. craniu - norma verticalis

Pl. 2 - Foto 5. mandibula - vedere superioară, Foto 6. humerus stâng şi cel drept - vedere anterioară, Foto 7. sacrum - vedere laterală, Foto 8 . coaxalul stâng - vedere externă

\section{Gabriel Vasile}

Muzeul Național de Istorie a României, Centrul Național de Cercetări Pluridisciplinare,

Calea Victoriei, 12, sector 3, 030026 Bucureşti, România, antropologie@mnir.ro 